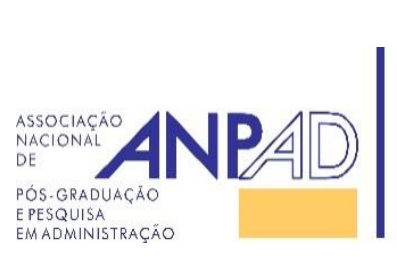

Available online at http://www.anpad.org.br/bar

BAR, Rio de Janeiro, v. 14, n. 1, art. 4, e160082, 2017

\title{
Gender Differences and Professional Identities in Health and Engineering
}

Adriane Vieira ${ }^{1}$ Alexandre de Pádua Carrieri ${ }^{1}$ Plínio Rafael Reis Monteiro ${ }^{1}$ Fátima Ferreira Roquete ${ }^{1}$

Universidade Federal de Minas Gerais ${ }^{1}$

Received 16 August 2016; received in revised form in 20 March 2017 (this paper has been with the authors for two revisions); accepted in 27 March 2017; first published online 10 April 2017. Editor's note. Juliana Cristina Teixeira served as Action Editor for this article. 


\begin{abstract}
The objective of this study was to compare the professional identity perceptions among undergraduate students enrolled in predominantly female and male courses. The research method is cross-sectional and the sample consisted of 502 undergraduate students in the fields of health and engineering. A questionnaire with the Scale of Professional Self and Hetero-Perception (EAHP) was used to collect the data and descriptive statistics, exploratory factor analysis, and structural equations modeling were used as analysis techniques. According to the students from the two areas, the dimensions that best describe their professions are dynamism; technicity; effort; and ethics, while in the health field, the dimension that received the lowest average score was recognition, indicating that the professionals working in this field resent the lack of respect, admiration, and prestige in society, despite perceiving themselves as honest, honored, productive, and hardworking. Also, the average hetero-perception scores were lower for the health students and the difference between self and hetero-perception was less significant among the engineering students. The results confirm that the professional identities include gender-related attributes, leading to the conclusion that health professions remain vulnerable to gender domination relations.
\end{abstract}

Key words: identity; profession; gender; health; engineering. 


\section{Introduction}

The increasing entry of women in the job market has caused profound changes in its dynamics. However, as for the occupation of positions, studies by Carrieri, Diniz, Souza and Menezes (2013), Capelle and Melo (2010) and Bruschini (2007) have shown that women in Brazilian organizations continue to play subordinate roles compared to their male counterparts, which reflects the maintenance of power relations.

At the international level, Gobillon, Meurs and Roux (2015) have shown that highly skilled men are more often hired than highly skilled women for high-paying jobs. In turn, Rice and Barth (2016) and Magee (2015) also point out to a substantial underrepresentation of women in the areas of technology, engineering, and mathematics, as well as in positions that require strong leadership skills. Härkönen, Manzoni and Bihagen (2016) have confirmed that men receive better rewards at work in terms of income, status, and promotion when compared to women.

According to Bimrose (2008), discrimination and segregation occur because stereotyped and sexist conceptions are developed since childhood, regarding what families and the society expect from girls and boys, especially as far as their vocational choices are concerned. Mothers and fathers educate their sons and daughters differently on issues involving daily responsibilities and chores, which entails implications for how these boys and girls will develop their professional and personal lives (Lundberg, 2005; Raley \& Bianchi, 2006).

Similarly to Carrieri et al. (2013), we understand that the concept of gender goes beyond the mere reproductive systems and the differences between men and women are the result of social construction. Therefore, gender inequalities are more strongly expressed in the scope of professional choices and insertion in the labor market, giving very specific contours to professional identities (Bruschini, 2007).

Our theoretical choice is the category of social and professional identity proposed by Dubar (2015). According to the author, the construction of the socio-professional identity results from the confrontation of two phenomena: the construction of the identity for the other and the construction of the identity for oneself. The author uses the term acts of identity attribution to refer to the construction process of the identity for the other, taken by the institutions and agents that directly interact with the individuals. However, for the sake of the analysis model used in this paper, the construction process of the identity for the other is referred to herein as hetero-perception. The process of building the identity for oneself, on the other hand, takes place through the acts of belonging, which according to Dubar (2015) express what kind of man or woman the subject wants to be. In other words, it is the unique identity of a person, resulting from his/her individual life history, is referred to herein as self-perception.

According to the author, two processes occur simultaneously in the construction of identities: the biographical and the relational process. The biographical identity process (the identity for itself) is strongly influenced by the spheres of work and employment, as well as by one's educational and professional training. The moment of leaving school and entering the labor market constitute the primary professional identity, which is not only an identity at work but also a projection of oneself in the future, which anticipates a trajectory of employment. Therefore, to build a biographical and professional identity, individuals must establish working relationships and participate in collective activities in organizations (Dubar, 2015).

Sutherland and Markauskaite (2012) and Sims (2011) clarify that an individual's professional identity is one of the different ones they can simultaneously support. The professional identity develops over time and, instead of being coherent and stable, is prone to change and more likely to be fragmented.

Like Dubar (2006, 2015), Miscenko and Day (2016) and Hay (2014) argue that the work category derives from various inputs, such as social identity and professional identity. For Koveshnikov, Vaara and Ehrnrooth (2016), the identity work has the power to construct situations and relationships in the workspace, configuring the subjectivities that are constantly negotiated in social interactions. 
Once we defined the theoretical categories of gender and social and professional identity, the research objective was to compare the self and hetero-perception of health and engineering students regarding the attributes that best characterize their professions.

To achieve this purpose, we started from the conclusions of Lundberg (2005) and Raley and Bianchi (2006). These authors state that cultural values, norms, and traditions measure the professional choices and career planning of young people since they establish different education paths, associated with the gender and the feeling of social belonging, defining which groups will be at risk or marginalized, as well as valued and rewarded. In summary, the key purpose of this paper is to identify and compare the professional attributes the students value most through self-perception, and how they believe society sees their professions through hetero-perception. In turn, this shall reveal aspects of the dynamic relation established between recognition and identification with the profession.

We adopted survey as the research method for this paper, with the participation of 502 graduate students of both genders. The health courses that agreed to participate were nursing, nutrition, biomedicine, and physiotherapy. The engineering courses were production, mechanical engineering, and metallurgy. The results confirmed that professional identities include attributes commonly associated with genders.

The results point to the absence of significant differences between the perceptions of female and male students within each area of knowledge (health and engineering), confirming that the image or status of a profession is linked to the power of the groups that naturalize which a profession should be occupied by men and women. In the health area, the dimension that received the lowest mean score was recognition and the difference between self and hetero-perception was lower for engineering students. We suggest that future studies include students from private institutions of education in their samples, as well as expand their database to comprise the perception of professionals who are already inserted in the job market.

This paper is organized in sections. The first section contains the theoretical framework and addresses the theme of gender and division of labor throughout human history, as well as its articulation with the construction of socio-professional identities. Following, we present the details of the research methodology, the data analysis, and the conclusions.

\section{Gender, Professional, and Labor Relations}

In accordance with the anthropologist Margareth Mead (1949), the identification with a gender is mediated by an apparatus of rules and physical and behavioral construction standards that shape the social identity based on the physical-biological substrate. The historian and feminist Joan Scott (1999) expanded the construction of gender by including the domination system through knowledge in her analyses. Along with the work of that author, gender constructions comprise images and meanings attributed to each sex, which determine how they relate. Therefore, the most important task is to analyze how the knowledge and hierarchies involving the genders are constructed and legitimized over time in a wide range of sociocultural contexts.

The origin of these differences begins to be constructed before birth, as Lundberg (2005) points out since the definition of what is expected from boys and girls starts even before birth and is clearly marked in babies' rooms by the colors of the furniture, clothing, decoration, and toys. The task division at home between mother and father and between male and female children also conditions what one can expect from one and the other in the life course. Traditionally, the fathers hardly encourage their male children to do housework, preventing them from trying out some roles they need to share responsibilities when they constitute their own families (Raley \& Bianchi, 2006).

The moment an individual enters the labor market, these internalized and externalized differences in patterns of behavior, habits, and attitudes do not dissolve, but instead, are reinforced. It should be 
noted that the entry of women into the labor market of the nineteenth century occurred precisely in professional activities associated with the act of caring, educating and serving, understood as a gift or vocation, and because of this very reason, they have maintained lower statuses and lower wages to this very day (Bruschini, 2007; Watt, 2010).

As Hugman (1991) explains, and more recently Kowalchuck (2016), among the occupations historically constructed as women's work are the caring professions, defined by the author as those whose members are committed to caring and performing tasks associated with care. Nurses, social workers, and physiotherapists take care of people, as well as lawyers, doctors, and architects, but in addition, they "care about people ... and often engage in unpleasant activities involving to body functions", explains the author (Hugman 1991, p. 423).

Therefore, care comes with two dimensions: care as a commitment (care for), predominantly associated with the historically female professions, such as nursing, social services and physiotherapy, and care as a task (care about), which is a socially considered notion more appropriate to refer to male professions, such as engineering, law, and medicine (McLaughlin, Muldoon, \& Moutray, 2010; Vargas, 2010).

According to Bruschini (2007), the increase of women in professions regarded as masculine began in Brazil in the 1970s. However, there are still discriminations such as horizontal segregation (Bimrose, 2008). In medicine, for instance, the female presence is more significant in certain specialties, such as pediatrics, dermatology, and gynecology. In engineering, female laborers are more frequent in the fields of production and chemical engineering, confirming that social stereotypes continue to demarcate the spaces occupied by men and women in those professional fields (T. Alves, 2009).

For Ismail and Nakkache (2015), the existence of gender inequality in the workplace is a problem in both developed and developing countries. Although the scenario has improved in recent years, men still receive better rewards at work in terms of income, status, promotion, and professional development than women, which constitutes a type of discrimination (Kowalchuck, 2016). In addition to this penalty, professional subjugation has happened through the definition of the attributions of men and women within the same professions, which in turn demarcates the spaces of each sex (Devi \& Somokanta, 2016).

\section{Identity Studies}

In accordance with Carrieri, Paula and Davel (2008), the theme of identity has attracted researchers from different fields, such as sociology, social psychology, anthropology, and psychoanalysis, and more recently the organizational theories. Therefore, the diversity of frameworks and perspectives in the field of social sciences has characterized the research on this subject.

In psychology, according to Oyserman, Elmore and Smith (2012), perspectives proliferated that associated identity with the concept of self, considered as what grants unity to the subject and his awareness of his singularity. The authors clarify that the term self is often used to refer to how I feel about me and about us. Hence, it refers to the existence of an I who is able to consider the existence of an object, which is the me. In short, the term self includes both the actor who thinks (I am thinking) and the object of the thinking (about me).

Identity, in turn, involves individual traits and characteristics, social relations and participations in social groups that define who one is (Oyserman, Elmore, \& Smith, 2012). It composes the selfconcept, that is, what comes to mind when one thinks about oneself and what one believes to be true about oneself (Burke, 2006).

The psycho-sociological and sociological approaches to identity personal contrast and social identities, which are also termed collective identities. Social identities, according to Tajfel (2010), 
involve the awareness that one is a member of a group, the feelings about the group members, and the awareness of the group's position or status compared to other groups.

According to Kristeva (1987), the identity construction implies that the subject must choose an identification and renounce others, as well as accept separations and ruptures, and this phenomenon is associated with the process of inclusion and exclusion in social groups. Hence, from the individual point of view, identification implies the constitution of self-representation and self-esteem, and from the social point of view, it involves the modalities of belonging to the groups, to the performance of roles and representations arising, including the professional ones.

The roles associated with the labor world comprise a part of the identity structure of individuals and, for this reason, we can consider the organization an important place of socialization, which comes to the point of modeling attitudes and behaviors, producing a professional, social and work identity (Dutton, Roberts, \& Bednar, 2010; Tajfel, 2010).

Beddoe (2011) states that professional identity can even be understood as a form of social identity, it develops over time and involves the attitudes, values, knowledge, beliefs, and abilities that are shared and learned in the social context and in the processes of professionalization.

For Carrillo, Baguley and Vilar (2015) social identity has a profound influence on what people choose as a profession. Therefore, complex and interrelated personal factors may affect it, such as gender, race (ethnicity), and religion.

According to Turner and Knight (2015), the professional identity not only involves how individuals perceive each other but also to how they are perceived by others and influenced by the interactions in the workspace. Moreover, professional identity need not remain constant, since identities can be reshaped through personal actions, changing the way the society perceives a given profession.

By analyzing the power and gender relations in the everyday practices of men and women managers working at a large general hospital, M. Alves, Brito, Melo, Lemos and Ferreira (2008) concluded that the prevailing identity attributes of female managers are: sensitivity; intuition; ability to listen; putting themselves in another person's shoes; giving feedback; managing conflicting situations; and being demanding. The male managers, in turn, are characterized by: objectivity; little attention to organizational life; speed; and exercising authority.

Studies such as the ones carried out by Melo and Lopes (2013) and Carrieri et al. (2013) and Capelle and Melo (2010) have confirmed that when women enter occupational spaces traditionally occupied by men, they end up reproducing male behavior patterns, due to implicit rules of the social environment into which they have been integrated. Added to that, they are often discriminated against their male counterparts.

The present study emerged in this scenario, with the proposal to identify possible stereotypes in professions considered more appropriate for each gender, based on the identity attributes that unite their members and distinguish them from the others.

\section{Research Method}

The research method used in this research was cross-sectional survey, aiming to study the characteristics of a group, surveying the opinions, attitudes, and beliefs, while exploring and analyzing data for the creation, formalization and/or renewal of knowledge areas (Cobanoglu, Warde, \& Moreo, 2001). The analysis was focused on health and engineering courses offered at the Federal University of Minas Gerais (Universidade Federal de Minas Gerais [UFMG]), which concentrates a large number of undergraduate courses in these areas. 
First, letters were sent to the course commissions, requesting authorization to apply the questionnaire in the classroom. The first courses in health that accepted were: nursing, nutrition, biomedicine, and physiotherapy. In engineering, the first courses to accept were: production, mechanical and metallurgical engineering. Table 1 displays the number of students enrolled in the courses per gender, as well as the respective percentages, provided by UFMG.

Table 1

Students Enrolled in Courses at UFMG in 2015 Distributed per Sex

\begin{tabular}{lccccc}
\hline \multicolumn{1}{c}{ Courses } & \multicolumn{2}{c}{ Male } & \multicolumn{2}{c}{ Female } & \multirow{2}{*}{ Grand Total } \\
\cline { 1 - 4 } & Total & \% & Total & \% & \\
\cline { 1 - 4 } Production Engineering & 234 & 57.4 & 174 & 42.6 & 408 \\
Mechanical Engineering & 741 & 88.5 & 96 & 11.5 & 837 \\
Metallurgical Engineering & 164 & 62.4 & 99 & 37.6 & 263 \\
Nursing & 39 & 9.1 & 390 & 90.9 & 429 \\
Nutrition & 35 & 11.9 & 258 & 88.1 & 293 \\
Biomedicine & 41 & 24.4 & 127 & 75.6 & 168 \\
Physiotherapy & 59 & 16.3 & 309 & 83.7 & 368 \\
Total & 1313 & 100 & 1453 & 100 & 2766 \\
\hline
\end{tabular}

Note. Field resource.

The presence of female students in the production engineering course is significant $(42.6 \%)$, followed closely by metallurgical engineering (37.6\%). In the health courses, on the other hand, the share of male students is small, with the highest percentage in biomedicine $(24.4 \%)$.

Data collection began with the four health courses. First, we contacted the course professors via e-mail, requesting authorization to apply the research in the classroom. On the date and time scheduled, the researchers applied and immediately collected the questionnaire responses. Since the students from the final course years were in training and therefore difficult to be reached, the course faculty sent a letter, elaborated by the researchers, inviting them to participate in the research through a link to the electronic questionnaire, available on Google Docs. Unfortunately, the response rate was very low, reaching about $10 \%$.

Data collection began in the second semester of 2014 and was closed off in June 2015, resulting in a sample of 251 students from each field of knowledge, totaling 502 respondents. The sample only included students from the fifth term onwards, who had already reached a more advanced stage of preparation to enter the labor market, and established connections with professionals of similar education background in different organizations. In theory, this allowed the learning of values and behaviors of their groups and a deeper understanding of the aspects that make up their professional identities. The questionnaire applied contained the Scale of Self and Hetero-Perception (Escala de Auto e Heteropercepção - EAHP), designed and validated by Vieira et al. (2016) (Table 2). The tool also included sociodemographic questions to characterize the research subjects. We chose not to perform the pre-test, once the researchers applied the instrument in person, allowing the clarification of doubts. 
Table 2

Dimensions and Professional Attributes of EAHP

\begin{tabular}{lll}
\hline \multicolumn{1}{c}{ Dimensions } & \multicolumn{1}{c}{ Attributes } \\
\hline 1. & Dedication & Friendly, partner, dedicated, humane \\
2. & Effort & Hard, exhausting, productive, hardworking \\
3. & Ethics & Ethical, honest, honored, trustworthy \\
4. & Technicity & Intelligent, wise, studious \\
5. Innovation & Creative, innovative \\
6. Recognition & Renowned, respected, admired, prestigious \\
7. Accomplishment & Optimistic, joyful, happy \\
8. Subordination & Obedient, submissive, dependent \\
9. Dynamism & Dynamic, stimulating, challenging \\
\hline
\end{tabular}

Note. Source: adapted from Vieira, A., Alves, M., Monteiro, P. R. R., Garcia, F. C., \& Santos, D. S. (2016). Construção de uma escala de auto e heteropercepção profissional (pp. 17-20). Revista de Administração FACES Journal, 15(2), 8-24. http://dx.doi.org/10.21714/1984-6975FACES2016V15N2ART2835

The respondents attributed scores between 1 and $5(1=$ describes very badly; and $5=$ describes very well) that best describe their professional category. Each attribute was scored twice, the first considering the way the respondent perceives his professional category (self-perception) and the second the perception he believes society has of his professional category (hetero-perception).

The participants' answers were registered in a database, using Statistical Package for Social Sciences - SPSS software, and analyzed using multigroup structural equation modeling (Tabachnick \& Fidell, 2007).

We used structural equation modeling using Partial Least Squares regression to test the construct validity and to verify the robustness of scales in the study. Results showed adequate levels of reliability and validity which allow applying scale scores to compare groups. The statistical t-test for independent samples was used to test the differences of means for each stratum (gender and course study group).

As the literature suggests (Hair, Black, Babin, \& Anderson, 2010; Tabachnick \& Fidell, 2007), the data were analyzed to check the premises required to analyze the data in the study. The number of missing data in the research was minimal: 546 missing answers ( $0.083 \%$ of the base) in a total of 65,260 cells (502 questionnaires x 130 variables). As this number is much lower than any potential concern $(5 \%)$, these data were replaced using the regression procedure. The univariate outliers were classified as answers beyond the quartile patterns (Q1 - 1.5*IQR, Q3 + 1.5*IQR) in each course, resulting in 668 negative and 473 positive coefficients, which were maintained in the analysis. The multivariate outliers were classified using the Mahalanobis distance $\left(\mathrm{D}^{2}\right)$ and divided by the number of variables. Cases in which the statistics surpassed 2.5 would be classified as multivariate outliers, but this type of case was not found, even when the sample was divided in the different research blocks to calculate the estimate. To analyze the normality, the asymmetry, we calculated the kurtosis estimates and applied the JarqueBera test.

For the asymmetry estimates, we found 12 coefficients beyond the interval of \pm 1 (76 significant coefficients) and, for the kurtosis, 17 coefficients beyond the proposed interval (46 significant) (Muthen \& Kaplan, 1992). In total, only eight variables could be considered normal according to the Jarque-Bera test. Given the large sample size, the deviation from normality is not considered problematic for the research, as the estimators used are resistant to the violation of this premise. Dispersion diagrams were drawn between 30 pairs of variables to test for linearity, to analyze apparent deviations that were left undetected. 
To verify the suitability of the research tool, we assessed the scales dimensions, the measuring quality, and the construct validity. An initial data reduction phase was undertaken, applying exploratory factor analysis (EFA) with main component extraction (varimax rotation). The data quality indicators to apply the EFA were considered satisfactory for KMO (superior to 0.80); suitability measures of individual variables (MSA's > 0.70); extracted variance (60\%); and commonalities superior to 0.40 .

Since the indicators did not converge into a single factor, we excluded the innovation dimension and its two attributes when testing the solution in the factor analysis.

\section{Sample Profile}

The male respondents (Table 3) from the field of engineering totaled $68 \%$ and the female respondents from the health area $89 \%$. The female presence in engineering courses corresponds to $32 \%$, while the male presence in health courses amounts to $11 \%$. Therefore, women's insertion in predominantly male courses is higher than the opposite, confirming that women have advanced in the search for equalitarian conditions in gender relations.

Most male and female respondents are single and are taking subjects in the fifth and seventh course semesters (76\% in engineering and $67 \%$ in health). The lesser presence of last-year students in the classroom was due to the fact that they were in training, and also due to the natural process of dropout and retention throughout the course. 
Table 3

\section{Sample Profile}

\begin{tabular}{|c|c|c|c|c|c|c|c|c|c|c|c|c|c|c|c|c|c|c|c|}
\hline & & \multicolumn{2}{|c|}{$\begin{array}{c}\text { Metallurgic } \\
\text { A }\end{array}$} & \multicolumn{2}{|c|}{$\begin{array}{c}\text { Production } \\
\text { B }\end{array}$} & \multicolumn{2}{|c|}{$\begin{array}{c}\text { Mechanical } \\
\text { C }\end{array}$} & \multicolumn{2}{|c|}{ Total } & \multicolumn{2}{|c|}{$\begin{array}{c}\text { Nursing } \\
\text { A }\end{array}$} & \multicolumn{2}{|c|}{$\begin{array}{l}\text { Nutrition } \\
\text { B }\end{array}$} & \multicolumn{4}{|c|}{$\begin{array}{cc}\text { Physiotherapy } & \text { Biomedicine } \\
\text { C } & \text { D }\end{array}$} & \multicolumn{2}{|c|}{ Total } \\
\hline & & Total & $\%$ & Total & $\%$ & Total & $\%$ & Total & $\%$ & Total & $\%$ & Total & $\%$ & Total & $\%$ & Total & $\%$ & Total & $\%$ \\
\hline \multirow{2}{*}{ Sex } & Male & 48 & $68 \%$ & 59 & $54 \%$ & 63 & $89 \% \%^{a b}$ & 170 & $68 \%$ & 5 & $14 \%$ & 3 & $5 \%$ & 9 & $10 \%$ & 10 & $17 \%$ & 27 & $11 \%$ \\
\hline & Female & 23 & $32 \% c$ & 50 & $46 \% c$ & 8 & $11 \%$ & 81 & $32 \%$ & 32 & $86 \%$ & 63 & $95 \%$ & 81 & $90 \%$ & 48 & $83 \%$ & 224 & $89 \%$ \\
\hline \multirow{8}{*}{$\begin{array}{l}\text { Course period } \\
\text { enrolled in }\end{array}$} & 5 & 14 & $20 \%$ & 16 & $15 \%$ & 17 & $24 \%$ & 47 & $19 \%$ & 3 & $8 \%$ & 1 & $2 \%$ & 23 & $26 \%$ & 15 & $26 \%$ & 42 & $17 \%$ \\
\hline & 6 & 24 & $34 \%$ & 29 & $27 \%$ & 19 & $27 \%$ & 72 & $29 \%$ & 18 & $49 \%$ & 26 & $39 \%$ & 27 & $30 \%$ & 14 & $24 \%$ & 85 & $34 \%$ \\
\hline & 7 & 16 & $23 \%$ & 14 & $13 \%$ & 18 & $25 \%$ & 48 & $19 \%$ & 3 & $8 \%$ & 35 & $53 \%$ & 34 & $38 \%$ & 10 & $17 \%$ & 82 & $33 \%$ \\
\hline & 8 & 6 & $8 \%$ & 12 & $11 \%$ & 8 & $11 \%$ & 26 & $10 \%$ & 13 & $35 \%$ & 3 & $5 \%$ & 4 & $4 \%$ & 8 & $14 \%$ & 28 & $11 \%$ \\
\hline & 9 & 10 & $14 \%$ & 19 & $17 \%$ & 5 & $7 \%$ & 34 & $14 \%$ & 0 & $0 \%$ & 1 & $2 \%$ & 2 & $2 \%$ & 5 & $9 \%$ & 8 & $3 \%$ \\
\hline & 10 & 1 & $1 \%$ & 15 & $14 \%$ & 2 & $3 \%$ & 18 & $7 \%$ & 0 & $0 \%$ & 0 & $0 \%$ & 0 & $0 \%$ & 3 & $5 \%$ & 3 & $1 \%$ \\
\hline & 11 & 0 & $0 \%$ & 2 & $2 \%$ & 1 & $1 \%$ & 3 & $1 \%$ & 0 & $0 \%$ & 0 & $0 \%$ & 0 & $0 \%$ & 3 & $5 \%$ & 3 & $1 \%$ \\
\hline & 12 & 0 & $0 \%$ & 2 & $2 \%$ & 1 & $1 \%$ & 3 & $1 \%$ & 0 & $0 \%$ & 0 & $0 \%$ & 0 & $0 \%$ & 0 & $0 \%$ & 0 & $0 \%$ \\
\hline \multirow{2}{*}{ Marital status } & Sing & 70 & $99 \%$ & 108 & $99 \%$ & 71 & $100 \%$ & 249 & $99 \%$ & 30 & $83 \%$ & 61 & $92 \%$ & 85 & $94 \%$ & 57 & $98 \%$ & 233 & $93 \%$ \\
\hline & Married & 1 & $1 \%$ & 1 & $1 \%$ & 0 & $0 \%$ & 2 & $1 \%$ & 6 & $17 \%{ }^{d}$ & 5 & $8 \%$ & 5 & $6 \%$ & 1 & $2 \%$ & 17 & $7 \%$ \\
\hline \multirow{5}{*}{$\begin{array}{l}\text { Monthly } \\
\text { Family } \\
\text { Income }\end{array}$} & $\mathrm{R} \$ 10,200$ or more & 22 & $31 \%$ & 50 & $46 \%$ & 31 & $44 \%$ & 103 & $41 \%$ & 2 & $5 \%$ & 4 & $6 \%$ & 8 & $9 \%$ & 7 & $12 \%$ & 21 & $8 \%$ \\
\hline & $\mathrm{R} \$ 5,100-\mathrm{R} \$ 10,199$ & 21 & $30 \%$ & 29 & $27 \%$ & 23 & $32 \%$ & 73 & $29 \%$ & 9 & $24 \%$ & 12 & $18 \%$ & 23 & $26 \%$ & 12 & $21 \%$ & 56 & $22 \%$ \\
\hline & $\mathrm{R} \$ 2,040$ - R\$ 5,099 & 19 & $27 \%$ & 22 & $20 \%$ & 8 & $11 \%$ & 49 & $20 \%$ & 17 & $46 \%$ & 27 & $41 \%$ & 27 & $30 \%$ & 27 & $47 \%$ & 98 & $39 \%$ \\
\hline & $\mathrm{R} \$ 1,020-\mathrm{R} \$ 2,039$ & 5 & $7 \%$ & 5 & $5 \%$ & 8 & $11 \%$ & 18 & $7 \%$ & 7 & $19 \%$ & 17 & $26 \%$ & 23 & $26 \%$ & 10 & $17 \%$ & 57 & $23 \%$ \\
\hline & Up to $\mathrm{R} \$ 1,019$ & 3 & $4 \%$ & 3 & $3 \%$ & 1 & $1 \%$ & 7 & $3 \%$ & 2 & $5 \%$ & 6 & $9 \%$ & 8 & $9 \%$ & 2 & $3 \%$ & 18 & $7 \%$ \\
\hline
\end{tabular}

Continues 


\section{Table 3 (continued)}

\begin{tabular}{|c|c|c|c|c|c|c|c|c|c|c|c|c|c|c|c|c|c|c|c|}
\hline & & \multicolumn{2}{|c|}{$\begin{array}{c}\text { Metallurgic } \\
\text { A }\end{array}$} & \multicolumn{2}{|c|}{$\begin{array}{c}\text { Production } \\
\text { B }\end{array}$} & \multicolumn{2}{|c|}{$\begin{array}{c}\text { Mechanical } \\
\text { C }\end{array}$} & \multicolumn{2}{|c|}{ Total } & \multicolumn{2}{|c|}{$\begin{array}{c}\text { Nursing } \\
\text { A }\end{array}$} & \multicolumn{2}{|c|}{$\begin{array}{l}\text { Nutrition } \\
\qquad \text { B }\end{array}$} & \multicolumn{2}{|c|}{$\begin{array}{c}\text { Physiotherapy } \\
\text { C }\end{array}$} & \multicolumn{2}{|c|}{$\begin{array}{c}\text { Biomedicine } \\
\text { D }\end{array}$} & \multicolumn{2}{|c|}{ Total } \\
\hline & & Total & $\%$ & Total & $\%$ & Total & $\%$ & Total & $\%$ & Total & $\%$ & Total & $\%$ & Total & $\%$ & Total & $\%$ & Total & $\%$ \\
\hline \multirow{2}{*}{ Works } & Yes & 10 & $14 \%$ & 29 & $27 \%$ & 14 & $20 \%$ & 53 & $21 \%$ & 10 & $27 \% c^{c}$ & 7 & $11 \%$ & 8 & $9 \%$ & 20 & $34 \%$ bc & 45 & $18 \%$ \\
\hline & No & 61 & $86 \%$ & 80 & $73 \%$ & 57 & $80 \%$ & 198 & $79 \%$ & 27 & $73 \%$ & 59 & $89 \%{ }^{d}$ & 82 & $91 \%$ & 38 & $66 \%$ & 206 & $82 \%$ \\
\hline \multirow{2}{*}{ Training } & Yes & 24 & $34 \%$ & 35 & $32 \%$ & 22 & $31 \%$ & 81 & $32 \%$ & 27 & $73 \%$ & 56 & $86 \%$ & 21 & $23 \%$ & 35 & $60 \%$ & 139 & $56 \%$ \\
\hline & No & 47 & $66 \%$ & 74 & $68 \%$ & 49 & $69 \%$ & 170 & $68 \%$ & 10 & $27 \%$ & 9 & $14 \%$ & 69 & $77 \%^{\text {abd }}$ & 23 & $40 \%$ & 111 & $44 \%$ \\
\hline \multirow{3}{*}{ Age range } & $<=22.00$ & 15 & $21 \%$ & 24 & $22 \%$ & 23 & $32 \%$ & 62 & $25 \%$ & 2 & $5 \%$ & 14 & $21 \%$ & 36 & $40 \%$ & 20 & $34 \%$ & 72 & $29 \%$ \\
\hline & $22.01-24.00$ & 38 & $54 \%$ & 44 & $40 \%$ & 29 & $41 \%$ & 111 & $44 \%$ & 14 & $38 \%$ & 27 & $41 \%$ & 40 & $44 \%$ & 20 & $34 \%$ & 101 & $40 \%$ \\
\hline & $24.01+$ & 18 & $25 \%$ & 41 & $38 \%$ & 19 & $27 \%$ & 78 & $31 \%$ & 21 & $57 \%$ & 25 & $38 \%$ & 14 & $16 \%$ & 18 & $31 \%$ & 78 & $31 \%$ \\
\hline & in Age & 23.3 & & 23.6 & & 23.2 & & 23.4 & & $26.6 *$ & & 24.2 & & 22.8 & & 23.6 & & 23.9 & \\
\hline
\end{tabular}

Note. Source: Field resource.

${ }^{a}$ The results are based on two-tailed tests, with 5\% significance level. For each pair with a significant difference, the letter of the category with the smallest proportion in the column is displayed under the category with the highest proportion.

* the mean age in the nursing course is higher than in all other courses. 
In the engineering courses, $41 \%$ of the students have a monthly family income of 10,200.00 BRL or more, and only $10 \%$ earn less than 1,020.00 BRL. In the health courses, the situation is practically the opposite, as only $8 \%$ of the students have a monthly family income of 10,200.00 BRL or higher, while $30 \%$ earn less than 2,039.00 BRL. These figures indicate that the courses involving healthcare are mainly occupied by women from the lower social classes of the Brazilian society, corresponding to a negative heritage typical of the female professions, in accordance with the studies by Bruschini (2007).

Confirming the studies by Watt (2010), the presence of men in careers dominated by women tends to be less significant because the wages and social status are lower. Therefore, men do not feel encouraged to pursue their interests and develop their skills in non-traditional domains; and when they do so, they are more prone to drop out than women.

The social value of the profession, as well as the remuneration, are historically constructed forms of penalization and subjugation of women's labor (Devi \& Somokanta, 2016; Kowalchuck, 2016). Furthermore, the discriminatory practices aim to undermine the women's persistence in occupying traditionally male professions (Smith \& Rosenstein, 2017).

\section{Self and Hetero-Perception of Engineering and Health Students: A Description}

In this item, the average scores in each of the eight domains of the scale of self and heteroperception are presented, as well as the differences in terms of the knowledge areas (engineering and health) and gender (male and female) (Table 4).

Table 4

Average Scores of Self and Hetero-perception per Gender and per Courses

\begin{tabular}{|c|c|c|c|c|c|c|}
\hline \multirow[b]{2}{*}{ Dimensions } & \multicolumn{2}{|c|}{ Engineering Courses } & \multicolumn{3}{|c|}{ Health Courses } & \multirow[b]{2}{*}{$\begin{array}{c}\mathrm{F} \\
\text { Total }\end{array}$} \\
\hline & $\begin{array}{c}\text { A } \\
\text { Male }\end{array}$ & $\begin{array}{c}\text { B } \\
\text { Female }\end{array}$ & $\begin{array}{c}\text { C } \\
\text { Total }\end{array}$ & $\begin{array}{c}\text { D } \\
\text { Male }\end{array}$ & $\begin{array}{c}\text { E } \\
\text { Female }\end{array}$ & \\
\hline \multicolumn{7}{|l|}{ Self-perception } \\
\hline Dynamism $^{\text {ns }}$ & 4.23 & 4.23 & 4.23 & 4.16 & 4.11 & 4.11 \\
\hline Recognition & $3.73 \mathrm{de}$ & $3.91 \mathrm{de}$ & $3.79 \mathrm{f}$ & 2.56 & 2.94 & 2.9 \\
\hline Accomplishment & 3.24 & 3.44 & 3.31 & 3.41 & 3.88abd & $3.83 \mathrm{c}$ \\
\hline Effort & 3.93 & 3.9 & 3.92 & 4.13 & 4.04 & $4.05 \mathrm{c}$ \\
\hline Technicity & 4.08 & 4.19 & 4.11 & 4.23 & $4.32 \mathrm{a}$ & $4.31 \mathrm{c}$ \\
\hline Ethics & 3.70 & $4.02 \mathrm{a}$ & 3.8 & $4.08 \mathrm{a}$ & $4.17 \mathrm{a}$ & $4.16 \mathrm{c}$ \\
\hline Dedication & 2.76 & 2.99 & 2.83 & $3.33 \mathrm{a}$ & 3.89abd & $3.83 \mathrm{c}$ \\
\hline Subordination & 2.66 & 2.63 & 2.65 & 2.88 & $3.08 \mathrm{ab}$ & $3.05 \mathrm{c}$ \\
\hline
\end{tabular}

Continues 
Table 4 (continued)

\begin{tabular}{|c|c|c|c|c|c|c|}
\hline \multirow[b]{2}{*}{ Dimensions } & \multicolumn{2}{|c|}{ Engineering Courses } & \multicolumn{3}{|c|}{ Health Courses } & \multirow[b]{2}{*}{$\begin{array}{c}\mathrm{F} \\
\text { Total }\end{array}$} \\
\hline & $\begin{array}{c}\text { A } \\
\text { Male }\end{array}$ & $\begin{array}{c}\text { B } \\
\text { Female }\end{array}$ & $\begin{array}{c}\text { C } \\
\text { Total }\end{array}$ & $\begin{array}{c}\text { D } \\
\text { Male }\end{array}$ & $\begin{array}{c}\text { E } \\
\text { Female }\end{array}$ & \\
\hline \multicolumn{7}{|l|}{ Hetero-perception } \\
\hline Dynamism & $3.95 \mathrm{de}$ & $3.97 \mathrm{de}$ & $3.96 f$ & 3.31 & 3.29 & 3.29 \\
\hline Recognition & $3.82 \mathrm{de}$ & $3.86 \mathrm{de}$ & $3.83 \mathrm{f}$ & 2.14 & $2.64 \mathrm{~d}$ & 2.58 \\
\hline Accomplishment & 2.94 & 3.14 & 3.01 & 2.98 & $3.4 \mathrm{a}$ & $3.36 \mathrm{c}$ \\
\hline Effort & $3.91 \mathrm{de}$ & $3.93 \mathrm{de}$ & $3.92 \mathrm{f}$ & 3.38 & 3.29 & 3.3 \\
\hline Technicity & $4.15 \mathrm{de}$ & $4.18 \mathrm{de}$ & $4.16 f$ & 3.41 & 3.51 & 3.5 \\
\hline Ethics ${ }^{\text {ns }}$ & 3.47 & 3.70 & 3.54 & 3.81 & 3.62 & 3.64 \\
\hline Dedication & 2.47 & 2.68 & 2.54 & $3.40 \mathrm{ab}$ & $3.55 \mathrm{ab}$ & $3.54 \mathrm{c}$ \\
\hline Subordination & 2.70 & 2.70 & 2.70 & $3.60 \mathrm{ab}$ & $3.43 \mathrm{ab}$ & $3.45 c$ \\
\hline \multicolumn{7}{|l|}{ Difference (Self - Hetero) } \\
\hline Dynamism & 0.28 & 0.26 & 0.27 & $0.84 \mathrm{ab}$ & $0.81 \mathrm{ab}$ & $0.82 \mathrm{c}$ \\
\hline Recognition & -0.09 & 0.05 & -0.04 & $0.42 \mathrm{a}$ & $0.31 \mathrm{a}$ & $0.32 \mathrm{c}$ \\
\hline Accomplishment ${ }^{\text {ns }}$ & 0.30 & 0.30 & 0.30 & 0.43 & 0.48 & $0.48 \mathrm{c}$ \\
\hline Effort & 0.02 & -0.03 & 0.00 & $0.75 \mathrm{ab}$ & $0.75 \mathrm{ab}$ & $0.75 c$ \\
\hline Technicity & -0.07 & 0.01 & -0.04 & $0.83 \mathrm{ab}$ & $0.81 \mathrm{ab}$ & $0.81 \mathrm{c}$ \\
\hline Ethics & 0.23 & 0.31 & 0.26 & 0.27 & $0.56 \mathrm{a}$ & $0.53 \mathrm{c}$ \\
\hline Dedication & 0.29 & 0.31 & 0.30 & -0.06 & $0.34 \mathrm{~d}$ & 0.29 \\
\hline Subordination & $-0.04 \mathrm{de}$ & $-0.07 \mathrm{~d}$ & $-0.05 f$ & -0.73 & -0.36 & -0.40 \\
\hline
\end{tabular}

Note. Source: Field resource.

a 'ns' indicates differences that are not statistically significant between the groups with significance set at $5 \%$. Two-tailed $t$ tests were applied to compare the columns, assuming equal variances with significance set at 5\%. For each significant pair, the letter of the category with the lowest average is displayed under the score of the category with the highest average.

According to the data in Table 4, the differences between female and male students in each area are very small. In the perception of respondents, the dimension that describe the professions in both areas well are: dynamism (4.23 in engineering and 4.11 in health); technicity (4.08 in engineering and 4.31 in health); ethics (3.80 in engineering and 4.16 in health); and effort (3.52 in engineering and 4.05 in health). Therefore, it is through these attributes that health students construct a concept of themselves, and wish to be recognized by the society, which ultimately legitimizes their identities and actions.

Dynamism was the predominant dimension in engineering and ranked third in health. It means that the students believe that the profession is dynamic, stimulating and challenging. Technicity is considered as the quality or condition of what is technical, that is, a specialized knowledge that will comply the function of distinguishing one professional group from another, that is, of helping in the construction process of group identities and of a certain professional status. This dimension ranked first in health and second in engineering and is associated with the attributes intelligent, wise, and studious, granting the profession certain scientific characteristics.

The ethical dimension ranked second in health and third in engineering. It is associated with noble attitudes, such as honesty, integrity, and trustworthiness, of strong appeal in health, in accordance with the studies by Vieira, Alves, Monteiro, Garcia and Santos (2016). The effort dimension ranked fourth 
in both areas. It is associated with an energic action of the body and/or mind and with the attributes hard, exhausting, productive, and hardworking.

The dedication dimension ranked fifth in health (3.54), together with accomplishment, and seventh in engineering (2.83). The dimensions that badly describe the professions were subordination in both areas (2.65 in engineering; 3.05 in health), and recognition (2.9) in health. The low average score for the recognition dimension (2.9) in the health area is another source of concern, as it indicates that this is the least representative attribute of the professional identity, as confirmed by the result of the hetero-perception scale (2.58).

On the hetero-perception scale, the dimension with the highest average score in engineering was technicity (4.16), followed by dynamism (3.96). The dimensions that badly describe the profession were dedication (2.54) and subordination (2.70), confirming the results of the self-perception scale.

Finally, the largest difference between self and hetero-perception for the respondents in health is found in dynamism (0.82), ethics (0.81), and effort (0.75), once again showing that the other does not correspond to the individuals' view on their professions, which can cause frustration. In engineering, on the other hand, a greater correspondence is identified between the students' and the society's perception, as the largest difference between self and hetero-perception corresponded to 0.30 in the dedication dimension.

\section{Analysis of the Professions Under the Students' Eyes: A Possible Gender Difference?}

When comparing the students' self and hetero-perception, it was not possible to identify significant differences in the way the two large groups characterize their professions, indicating, on the contrary, a similarity in the structure of social values, involving both genders, since men and women enrolled in courses with female predominance perceived themselves with the same attributes as those inserted in predominantly masculine ones.

However, the relationships between gender identities and professional identities, as well as the way each individual manifests his/her self and hetero-perception, can be better explained by order of priority in the selection of these attributes in each field of knowledge, which reveals the presence of certain stereotypes and possible discrimination.

A person's profession represents much more than their aptitudes and functions; it is a form of life to be assumed, as the relation between the workers and their profession is characterized by the engagement and by the feeling of identity and compliance with its attributes. The professional identity, therefore, plays a vital role in how individuals give meaning to our work environment and manage their careers; it is an important input for the construction of work identity (Dubar, 2015; Hay, 2014; Miscenko \& Day, 2016).

Through the adjective choice, the students described their professions as dynamic, technical, ethical, and hardworking. Therefore, these attributes favor the identification with their professional group and, at the same time, the distinction from other groups. At the same, they will guide their behaviors in society (Burke, 2006; Zikic \& Richardson, 2015).

Specialized knowledge, tied to ethical behavior, has a slightly stronger appeal in the health area, which can be explained by the fact that professionals deal with lives at risk most of the time. As Hugman (1991) and Kowalchuck (2016) point out, health professionals perform the act of caring as a commitment, because they care for others, a typically female behavior. The role played by women in another professional field, such as engineering, may have a different connotation, and be imbued with more rationality and emotional detachment, that is, the act of caring as a task (care about). 
The word care conveys an idea of concern, but also of the sexual division of labor in society; that is, the act of caring for other human beings, a function that is historically and socially attributed to women (Hugman, 1991; Kowalchuck, 2016). Here, then, it is a gender mark that separates the professions, and defines the most appropriate attitudes and behaviors for women and men. By internalizing these attributes, women reproduce the socio-professional role assigned to them by society and reveal how gender and work identities are articulated and condition actions in social groups of belonging.

Another element that most strongly characterizes female work in health is physical effort. Studies involving nursing professionals (Menzel, 2008), for example, indicate that the repetitive movements and the need to constantly move sometimes obese patients may cause musculoskeletal injuries. The rhythm and the intense work load also characterize these workers' everyday reality, mainly at hospitals and medical emergency services.

However, the dedication dimension is the most revealing of the differences between genders that mark these two professional areas (3.83 points in health; 2.83 points in engineering), once, the attributes (friend, partner, dedicated and humane) are strongly linked with the female role in society and enclose a strong emotional aspect, as the studies by M. Alves et al. (2008) Capelle and Melo (2010), Melo and Lopes (2013), and Carrieri et al. (2013) have confirmed.

Nevertheless, the bottom rank in health reveals that health professionals want to keep a distance from such attributes and to be predominately characterized by their technical capacity, above all.

Subordination, on the other hand, is the attribute that badly describes the professional identities of students of both areas and genres. This dimension is linked to characteristics regarded as derogatory, such as obedience, submission, and dependence, which have historically characterized the work performed by individuals of low social status in the Brazilian scenario.

The first professions constituted at the start of the $19^{\text {th }}$ century in Brazil were medicine, engineering, and law, which were known as the imperial professions (Vargas, 2010). In that period, most of the people in the country were slaves and illiterate; attending university was a luxury accessible only to a small elite, whose monopolistic practices strengthened its positions of prestige in relation to the other professions. Therefore, it is no surprise that such dimension does not characterize engineering. However, it is necessary to deepen the analysis to say the same of the health professions, since the attributes of this dimension (obedience, submission, and dependence) have been historically associated with the role of women in patriarchal societies.

According to Narvaz and Koller (2006), since the colonization, women's position in the Brazilian society have demonstrated that the patriarchal family was and still is one of the matrices of our social organization. The shape of the modern patriarchy has changed but preserved the premises of traditional patriarchal thinking, which involves the propositions that assume the father's power in the family as the origin and model of all relationships of power and authority (Saffioti, 2004).

Studies such as Prochnow, Leite, Erdmann and Trevizan (2007) and Tabak and Orit (2007), for example, have pointed that the social relations established between physicians and other health professionals, particularly nurses, are based on tensions and conflicts deriving from the physicians greater power and control over the work process, in function of their sovereign autonomy in the decisions involving the diagnosis and prescription of medication for the patients.

Medicine is also an imperial profession and, as such, preserves remnants of the authoritarianism characteristic of the Brazilian elites, particularly when the gender domination relations are at stake. Therefore, the attempts to subordinate the other professions may still be present in the health area. This argument rests on the fact that the subordination dimension obtained a relatively high score on the hetero-perception scale (3.45), informing that society still characterizes these professions as such (submissive and obedient), granting them a low social status. 
Since the difference between self and hetero-perception in this dimension was high (-0.40), we conclude that professionals would not like to be seen that way, indicating their refusal to accept the identification of this attribute for the other. As Dubar (2015) and Koveshnikov et al. (2016) point out, the social world is the space where we endorse or reject the identifications we receive from others and institutions, and build our professional and working identities.

The most worrying data for the construction of professional identities in the health area, however, is the low score obtained in the recognition dimension. This indicates that these such identify a lack of respect, admiration and recognition for the services provided in the relationship between the health professional and their colleagues and patients, which is built in the workspace. This, in turn, can lead to moral suffering.

Therefore, we identify the existence of a problematic conflict, which may compromise the confirmation and legitimation of professional and work identities, which are still under construction, and which must be addressed by educational institutions. Disregarding this aspect during vocational training may have negative consequences for employers when it comes to the quality of services and relationships, such as high absenteeism, conflicts, accidents, process errors, customer complaints, and waste, among others.

As Vieira, Alves, Monteiro and Garcia (2013) have alerted, the risk that accompanies the construction of professional identities is that when we assume that the view of the other is not loaded with respect and admiration, self-esteem diminishes and frustration ensues, which can lead to serious harm to the health of workers and organizations.

Having a prestigious and renowned professional image culminates in less suffering and greater professional accomplishment, also promoting the identification with the organization, as the "professional recognition significantly affects the identification with the organization" (Vieira, Alves, Monteiro, \& Garcia, 2013, p. 8).

Therefore, the results confirm that the image or status of a profession is socially constructed and tied to the cultural, political, and economic contexts of each society and to the power struggles among established groups. Moreover, although group stereotypes seem more prominent than gender stereotypes in the construction of identities, this does not mean that the gender disequilibrium has ceased to exist in each profession.

\section{Conclusion}

The objective in this study was to compare the self and hetero-perception of students in health and engineering regarding the attributes that best characterize their professions, departing from the premise that the professional identities include attributes associated with the male and female gender.

The absence of significant differences between the female and male students' perceptions in each field of knowledge (health and engineering) confirms that the image or status of a profession is socially constructed and linked to the power of those groups, which constructs and naturalizes the notion that there are more suitable professions for women and others more suitable for men.

We also identified that the attributes most strongly associated with the female gender, represented by the dedication dimension (friend, partner, dedicated and humane) are hardly associated with the professional identities in the health area, according to the students' self-perception (identity for oneself). This indicates the non-acceptance of the traditional and natural association between the work the health professionals develop (the caring professions) and the work women perform at home. This can represent a generational change in terms of labor relations, for there is also an economic relation behind one's professional choice. On the other hand, we may think that the separation of the care of the people and 
of the house/family can bring another look at the domestic tasks and the raising of children, which in our society are still recognized as feminine.

The fact that the health students chose the same attributes to characterize their professions as the engineering students (dynamism, technicity, effort, and ethics) indicates a posture of confrontation and search for equality in gender relations. Nevertheless, this does not mean that these men and women in the same profession will compete as equals in the job market. This happens because at when disputing over a job, they will be distinguished not only by the professional identity but also by the gender identity, which can serve as a tiebreaker. Therefore, a long road remains ahead for women in their search for gender equality. Simply check that submission, obedience, and passiveness are attributes the society associates with their professions (hetero-perception).

We should also highlight that, in health, the dimension with the lowest average was recognition, confirming that the professionals in this group resent the lack of respect, admiration, and prestige in society, although they perceive themselves as honest, honored, productive and hardworking.

In addition, the average hetero-perception scores were lower for the health students, and the difference between self and hetero-perception was smaller for the students in engineering. These data confirm that some professions are penalized, not only objectively (monetarily), but also subjectively, i.e. through low recognition, stereotyping and discriminatory practices, such as the studies by Kowalchuck (2016), Devi and Somokanta (2016), and Smith and Rosenstein (2017) indicate.

The engineering area experiences a much more comfortable situation, for it is a traditional profession that emerged in the imperial period, has been restricted to men for a long time and has historically enjoyed prestige and social status. On the other hand, the situation the health professionals face indicates a possible crack or identity crisis, that is, the dissociation of oneself which happens when the effort to comply with the group in search of recognition is weakly corresponded or ignored by the others.

This research entailed questions about the construction of professional identities mediated by gender issues, which deserve to be further explored through new studies, especially with qualitative designs, such as the external and internal strategies health professionals use to deal with this distance between the self and hetero-perception, with a view to accommodating the identity for themselves in the identity for the other. In addition, we suggest that future studies include students from private educational institutions and other courses and professions, and expand their database, to comprise the perception of professionals who are already active in the job market, so that one can establish comparisons between theoretical categories of professional and work identity, as Sutherland and Markauskaite (2012) suggest.

One of the limitations of this study was the difficulty of comparing the results, as similar studies were not found in the literature.

As for the research contributions, all course coordinators received a report to help them reflect on the attributes that identify their professions and how society has confirmed or denied such identities, i.e. the relationship between acts of belonging and acts of attribution. Regarding gender relations, the challenge for all those involved, including working organizations, is to create spaces so that issues of prejudice and inequality are addressed in a clear and transparent manner, allowing the development of strategies that restrict discrimination and preserve the status of each profession.

We hope this research on gender and professional identity allows a better understanding of the relationship between socio-historical and cultural conditions, gender, and professional identity, as well as provide some basis for educational institutions and organizations to develop policies to solve discrimination and segregation issues. 


\section{References}

Alves, M., Brito, M. J. M., Melo, M. C. O. L., Lemos, L. P., \& Ferreira, M. A. (2008, junho). Práticas de gestão, relações de poder e de gênero na organização hospitalar. Anais do Encontro de Estudos Organizacionais da ANPAD, Belo Horizonte, Minas Gerais, Brasil, 5.

Alves, T. (2009). Profissões sociais e género: perspectivas em torno do debate sobre serviço social e profissões femininas. Locus SOCI@L, 2, 21-28. Retrieved from http://cesss.fch.lisboa.ucp.pt/images/site/locus-social/locus-social-n2-2009.pdf

Beddoe, L. (2011). Health social work: professional identity and knowledge. Qualitative Social Work, 1(1), 1-17. http://dx.doi.org/1473325011415455

Bimrose, J. (2008). Guidance with women. In J. Athanasou \& R. V. Esbroeck (Eds.), International handbook of career guidance (pp. 375-404). Dordrecht: Springer.

Bruschini, M. C. A. (2007). Trabalho e gênero no Brasil nos últimos dez anos. Cadernos de Pesquisa, 37(132), 537-572. http://dx.doi.org/10.1590/S0100-15742007000300003

Burke, P. J. (2006). Identity change. Social Psychology Quarterly, 69(1), 81-96. http://dx.doi.org/10.1177/019027250606900106

Capelle, M. C. A., \& Melo, M. C. O. L. (2010). Mulheres policiais, relações de poder e de gênero na Polícia Militar de Minas Gerais. Revista de Administração Mackenzie, 11(2), 71-99. http://dx.doi.org/10.1590/S1678-69712010000300006

Carrieri, A. de P., Diniz, A. P. R., Souza, E. M., \& Menezes, R. S. S. (2013). Gender and work: representations of femininities and masculinities in the view of women Brazilian executives. Brazilian Administration Review, 10(3), 281-303. Retrieved from: http://www.scielo.br/pdf/bar/v10n3/aop0213.pdf

Carrieri, A. de P., Paula, A. P. P. de, \& Davel, E. (2008). Identidade nas organizações: Múltipla? Fluida? Autônoma?. Organizações \& Sociedade, 15(45), 128-144. Retrieved from https://portalseer.ufba.br/index.php/revistaoes/article/view/10954/7880

Carrillo, C., Baguley, M., \& Vilar, M. (2015). The influence of professional identity on teaching practice: experiences of four music educators. International Journal of Music Education, 33(4), 451-462. http://dx.doi.org/10.1177/0255761415582348

Cobanoglu, C., Warde, B., \& Moreo, P. J. (2001). A comparison of mail, fax and web-based survey methods. International Journal of Market Research, 43(4), 441-452.

Devi, W. P., \& Somokanta, T. (2016). Gender, technology, and work case of women employees in selected food processing industries in Manipur. Gender, Technology and Development, 20(1), 81104. http://dx.doi.org/10.1177/0971852415619497

Dubar, C. (2006). A crise das identidades. A interpretação de uma mutação. Porto: Afrontamento.

Dubar, C. (2015). La socialisation: construction des identités sociales et professionnelles (5ème ed.). Paris: Armand Colin.

Dutton, J. E., Roberts, L. M., \& Bednar, J. (2010). Pathways for positive identity construction at work: four types of positive identity and the building of social resources. Academy of Management Review, 35(2), 265-293. Retrieved from http://amr.aom.org/content/35/2/265.full

Gobillon, L., Meurs, D., \& Roux, S. (2015). Estimating gender differences in access to jobs. Journal of Labor Economics, 33(2), 317-363. http://dx.doi.org/10.1086/678495 
Hair, J. F., Black, W. C., Babin, B. J., \& Anderson, R. E. (2010). Multivariate data analysis (7th ed.). New Jersey: Prentice Hall, Upper Saddle River.

Hay, A. (2014). 'I don't know what I am doing!': surfacing struggles of managerial identity work. Management Learning, 45(5), 509-524. http://dx.doi.org/10.1177/1350507613483421

Härkönen, J., Manzoni, A., \& Bihagen, E. (2016). Gender inequalities in occupational prestige across the working life: an analysis of the careers of West Germans and Swedes born from the 1920s to the 1970s. Advances in Life Course Research, 29, 41-51. http://dx.doi.org/10.1016/j.alcr.2016.01.001

Hugman, R. (1991). Power in caring professions. London: The Macmillan Press.

Ismail, H. N., \& Nakkache, L. (2015). Gender differences at work: experiencing human resource management policies in Lebanese firms. Global Business Review, 16(6), 907-919. http://dx.doi.org/10.1177/0972150915597592

Koveshnikov, A., Vaara, E., \& Ehrnrooth, M. (2016). Stereotype-based managerial identity work in multinational corporations. Organization Studies, 37(9), 1353-1379. http://dx.doi.org/10.0170840616634129

Kowalchuk, L. (2016). Nurses' labor conditions, gender, and the value of care work in post-neoliberal El Salvador. Critical Sociology, 10, 91-142. http://dx.doi.org/10.1177/0896920516675203

Kristeva, J. (1987). Le réel de l'identification. In M. David-Ménard, J. Florence, J. Kristeva, G. Michaud, J. Oury, J. Schotte, \& C. Stein (Eds.), Les identifications: confrontation de la clinique et de la théorie de Freud à Lacan (pp. 47-77). Paris: L'espace analytique, Denoël.

Lundberg, S. (2005). Sons, daughters, and parental behaviour. Oxford Review of Economic Policy, 21(3), 340-356. http://dx.doi.org/10.1093/oxrep/gri020

Magee, W. (2015). Effects of gender and age on pride in work, and job satisfaction. Journal of Happiness Studies, 16(5), 1091-1115. http://dx.doi.org/10.1007/s10902-014-9548-x

McLaughlin, K., Muldoon, O. T., \& Moutray, M. (2010). Gender, gender roles and completion of nursing education: a longitudinal study. Nurse Education Today, 30(4), 303-307. http://dx.doi.org/10.1016/j.nedt.2009.08.005

Mead, M. (1949). Male and female: a study of the sexes in a changing world. England: Oxford.

Melo, M. C. D. O. L., \& Lopes, A. L. M. (2013). Empoderamento de mulheres gerentes: a construção de um modelo teórico de análise. Gestão \& Planejamento-G\&P, 13(3), 648-667. Retrieved from http://www.revistas.unifacs.br/index.php/rgb/article/view/2346

Menzel, N. N. (2008). Underreporting of musculoskeletal disorders among health care workers research needs. AAOHN Journal, 56(12), 487-494. http://dx.doi.rg/10.3928/08910162-20081201-06

Miscenko, D., \& Day, D. V. (2016). Identity and identification at work. Organizational Psychology Review, 6(3), 215-247. http://dx.doi.org/10.2041386615584009

Muthen, B., \& Kaplan, D. A. (1992). Comparison of some methodologies for the factor analysis of nonnormal Likert variables: a note on the size of the model. British Journal of Mathematical and Statistical Psychology, 45(1), 19-30. http://dx.doi.org/10.1111/j.2044-8317.1992.tb00975.x

Narvaz, M. G., \& Koller, S. H. (2006). Famílias e patriarcado: da prescrição normativa à subversão criativa. Psicologia \& Sociedade, 18(1), 49-55. http://dx.doi.org/10.1590/S010271822006000100007 
Oyserman, D., Elmore, K., \& Smith, G. (2012). Self, self-concept, and identity. In M. Leary \& J. Tangney (Eds.), Handbook of self and Identity (pp. 69-104). New York: Guilford.

Prochnow, A. G., Leite, J. L., Erdmann, A. L., \& Trevizan, M. A. (2007). O conflito como realidade e desafio cultural no exercício da gerência do enfermeiro. Revista da Escola de Enfermagem da USP, 41(4), 542-550. http://dx.doi.org/10.1590/S0080-62342007000400002

Raley, S., \& Bianchi, S. (2006). Sons, daughters, and family processes: does gender of children matter? Annual Review of Sociology, 401-421. http://dx.doi.org/10.1146/annurev.soc.32.061604.123106

Rice, L., \& Barth, J. M. (2016). Hiring decisions: the effect of evaluator gender and gender stereotype characteristics on the evaluation of job applicants. Gender Issues, 33(1), 1-21. http://dx.doi.org/10.1007/s12147-015-9143-4

Saffioti, H. I. B. (2004). Gênero, patriarcado, violência. São Paulo: Fundação Perseu Abramo.

Scott, J. W. (1999). Gender and the politics of history. New York: Columbia University Press.

Sims, D. (2011). Reconstructing professional identity for professional and interprofessional practice: a mixed methods study of joint training programmes in learning disability nursing and social work. Journal of Interprofessional Care, 26, 25-271. http://dx.doi.org/10.3109/13561820.2011.571352

Smith, D. G., \& Rosenstein, J. E. (2017). Gender and the military profession early career influences, attitudes, and intentions. Armed Forces \& Society, 43(2), 260-279. http://dx.doi.org/10.1177/0095327X15626722

Sutherland, L., \& Markauskaite, L. (2012). Examining the role of authenticity in supporting the development of professional identity: an example from teacher education. Higher Education, 64(6), 747-766. http://dx.doi.org/10.1007/s10734-012-9522-7

Tabachnick, B. G., \& Fidell, L. S. (2007). Using multivariate statistics (5th ed.). Boston: Pearson/Allyn \& Bacon.

Tabak, N., \& Orit, K. (2007). Relationship between how nurses resolve their conflicts with doctors, their stress and job satisfaction. Journal of Nursing Management, 15(3), 321-331. http://dx.doi.org/10.1111/j.1365-2834.2007.00665.x

Tajfel, H. (2010). Social identity and intergroup relations. Cambridge: University Press.

Turner, A., \& Knight, J. (2015). A debate on the professional identity of occupational therapists. British Journal of Occupational Therapy, 78(11), 664-673. http://dx.doi.org/10.0308022615601439

Vargas, H. M. (2010). Sem perder a majestade: profissões imperiais no Brasil. Estudos de Sociologia, 15(28), 107-124. Retrieved from http://seer.fclar.unesp.br/index.php/estudos/article/viewFile/2553/2173

Vieira, A., Alves, M., Monteiro, P. R., \& Garcia, F. C. (2013). Women in nursing teams: organizational identification and experiences of pleasure and suffering. Revista Latino-Americana de Enfermagem, 21(5), 1127-1136. http://dx.doi.org/10.1590/S0104-11692013000500016

Vieira, A., Alves, M., Monteiro, P. R. R., Garcia, F. C., \& Santos, D. S. (2016). Construção de uma escala de auto e heteropercepção profissional. Revista de Administração FACES Journal, 15(2), 8-24. http://dx.doi.org/10.21714/1984-6975FACES2016V15N2ART2835

Watt, H. M. (2010). Gender and occupational choice. In J. C. Chrisler \& D. R. McCreary, Handbook of gender research in psychology (pp. 379-400). New York: Springer. 
Zikic, J., \& Richardson, J. (2015). What happens when you can’t be who you are: professional identity at the institutional periphery. Human Relations, 69(1), 139-168. http://dx.doi.org/10.0018726715580865

\title{
Authors' Profiles
}

\author{
Adriane Vieira \\ UFMG/Enfermagem Aplicada, Av. Prof. Alfredo Balena, 190, 30130-100, Belo Horizonte, MG, Brazil. E-mail address: \\ vadri.bh@gmail.com \\ Alexandre de Pádua Carrieri \\ Cepead/CAD/UFMG, Av. Antônio Carlos, 6627, 31270-901, Belo Horizonte, MG, Brazil. E-mail address: \\ aguiar.paduacarrieri@terra.com.br \\ Plínio Rafael Reis Monteiro \\ Cepead/CAD/UFMG, Av. Antônio Carlos, 6627, 31270-901, Belo Horizonte, MG, Brazil. E-mail address: \\ preisufmg@gmail.com \\ Fátima Ferreira Roquete \\ UFMG/Enfermagem Aplicada, Av. Prof. Alfredo Balena, 190, 30130-100, Belo Horizonte, MG, Brazil. E-mail address: \\ fatimaroquete@gmail.com
}

